\title{
The Influence of Product and Service Quality Toward Customer Satisfaction at Fast Food Restaurant in Banda Aceh, Aceh Province
}

\author{
Ivon Jalil

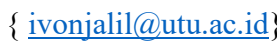 \\ Lecturer in Faculty of Economic University of Teuku Umar Alue Peunyareng, West Aceh, Aceh, \\ Indonesia
}

\begin{abstract}
The study aims to illustrate clearly about product and servive quality and customer satisfaction at fast food restaurants in Banda Aceh. Besides, the purpose of this research is to analyze the influence of product quality toward customer satisfaction. The population of this study was consumers at some fast food restaurants in Banda Aceh. The method used in this study is a descriptive quantitative method. In addition, the data used is primary data which is obtained by the respondents as many as 145 respondents with purposive sampling. Research analysis is conducted by applying SEM with equation structural model with data processing using Amos program. The result of descriptive analysis indicated that product quality at fast food restaurants in Banda Aceh has been running well however the quality service is not especially at tangible dimension, resposiveness and reliability. The results of hypothesis testing showed that product quality affects consumer satisfaction and affects consumers in maintaining making purchases at certain fast food restaurants in Banda Aceh.
\end{abstract}

Keyword: product quality, fast food product, consumer satisfaction and customer

\section{Introduction}

\subsection{Background}

Nowadays, the franchise business has been growing. One type of franchise business that is often found in the world is fast food. These fast food outlets were initially started in the 19th century, when the United States entered the industrial era which caused many workers to only have short breaks and long working hours. That reasons encouraged workers to prefer foods served by fast food outlets because the speed in serving and the taste is also delicious. This advantage makes fast food outlets spread in the United States. In the 20th century, the business of fast food outlets increasingly spread to the continents of Europe, Africa, Australia and Asia such as Indonesia with a franchise concept.

Fast food restaurants began to operate in Indonesia around the 1980s, started with the existence of KFC (Kentucky Fried Chicken), then followed by McDonald's and others. Fast food restaurants are growing rapidly in Indonesia, especially in urban areas, in response to modern lifestyles with increasing flexibility. By the change in lifestyle and the increasing acceptance of fast food restaurants by the community, there are 5 largest fast food restaurant companies originating from foreign countries in Indonesia, namely McDonald's, KFC, Dunkin Donuts, Pizza Hut and Hoka Hoka Bento (www.wikipedia.org) [1].

In Banda Aceh, fast food restaurants have growth in the last 5 years, especially fast food restaurants of foreign franchises. Initially, there was only one oulet and one fast food restaurant industry, namely KFC (Kentucky Fried Chicken). After tsunami, fast food 
restaurants in Banda Aceh City grew rapidly with the emergence of new fast food restaurants such as A \& W and Pizza Hut. Until now, there are 7 fast food restaurant outlets in the city of Banda Aceh: 4 KFC oulets, 2 Pizza Hut oulets and 1 A \& W oulet.

The presence of fast-food foreign franchise restaurants in the food industry in Banda Aceh influences people's eating patterns, especially for the upper middle class, including customer satisfaction. Customer satisfaction is a feeling of pleasure or disappointment that comes from a comparison between the impression of the performance (results) of a product with its expectations. Generally, customer expectations are an estimate or a confidence of the customer about what he will receive if he buys or consumes a product, while perceived performance is the customer's perception of what he receives after consuming the product purchased.

Based on the writer's observations, it is different from what is felt by consumers of fast food restaurants in Banda Aceh, where consumers felt that the performance and quality of service at fast food restaurants are still below expectations especially at certain hours, so that a sense of dissatisfaction arises. The lack of satisfaction achieved by consumers of fast food restaurants is evidenced by the emergence of various

complaints, including the lack of parking space, consumer inconvenience with the restaurant atmosphere, no food avaibility, a product mismatch as promised and long queues at hours certain hours.

Product quality is one of the factors that play an important role in influencing the level of consumer satisfaction. The phenomena happening in fast food restaurants in Banda Aceh is consumers still complain about the quality of some of the products offered. Service quality is the customer's assessment of the superiority or features of a product or service as a whole which starts from the customer's needs and ends with the customer's perception. There are many things that need to be considered in maintaining the quality of services including physical evidence, reliability, responsiveness, assurance, empathy. This is different from the case felt by consumers of fast food restaurants in Banda Aceh where consumers have not fully enjoyed the services of restaurant officers such as the limited parking space provided to some fast food restaurants that consumers often complain about, the maximal malfunction of the equipment provided such as a jammed wastafle, hand washing soap run out and a broken hand dryer machine often makes consumers disappointed.

\subsection{Problem Formulation}

The formulation of the problems that will be discussed in this study are:

- Does product quality affect consumer satisfaction of fast food restaurants in Banda Aceh?

- Does the quality of service affect customer satisfaction of fast food restaurants in Banda Aceh?

\subsection{Research Objectives}

The purpose of this study is:

- To analyze the effect of product quality on customer satisfaction of fast food restaurants in Banda Aceh.

- To analyze the effect of service quality on consumer satisfaction of fast food restaurants in Banda Aceh. 


\section{Literature Review}

\subsection{Consumer Satisfaction}

Consumer satisfaction is reflected in the interest after the purchase of an item / service. Buying interest is the tendency of respondents to act before the buying decision is actually implemented (Kinnear and Taylor, 2003)

Furthermore (Arief, 2007, p. 148) suggested that the consumer satisfaction with a service is determined by the level of consumer expectations before using services.

Furthermore, outline of the customer satisfaction concept in the view of (Zeithaml and Bitner, 2010, p. 75) is as follows:

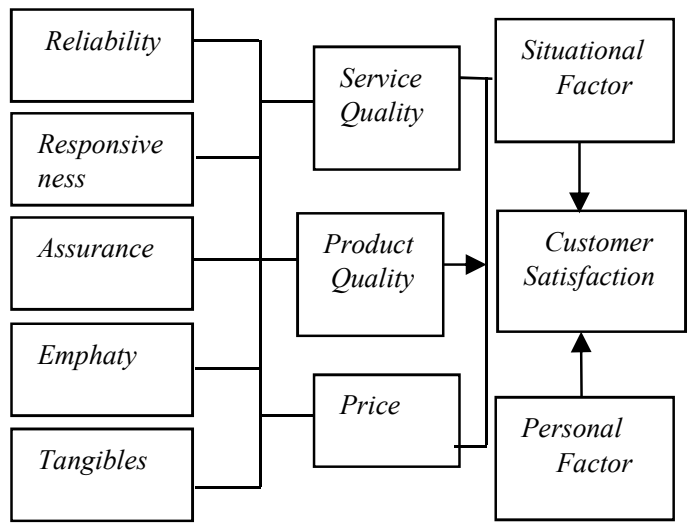

Fig. 1. Outline of Customer Satisfaction Concept

Figure 1 above explains that basically there are 5 (five) assessments of quality, namely reliability, responsiveness, assurance, empathy, and tangibles, where they affect the quality of service, product quality and product prices. Furthermore, these three factors, both together and alone will affect customer satisfaction.

\section{Research Methods}

\subsection{Location and Object of Research}

This research was conducted at Fast Food Restaurants located in Banda Aceh City. The object of this research relates to what and how the influence of product and service quality on consumer satisfaction.

\subsection{Population and Sample}

This study used purposive sampling technique, as many as 145 respondents.

\subsection{Data Collection Techniques}

Data collection method used in this study was a survey method that used a list of statements (questionnaires) that were submitted directly to respondents with a Likert scale. 


\subsection{Test Validity and Reliability}

The data were analyzed by testing validity and reliability.

\subsection{Structural Equation Modeling Analysis}

The data used were analyzed by using The Structural Equation Modulation (SEM) of AMOS statistical software package in the model and hypothesis assessment. SEM equation model is a set of statistical techniques that allow testing a series of relatively "complicated" relationships simultaneously (Ferdinand, 2014, p. 181).

\section{Results And Discussion}

\subsection{Characteristics of Respondents}

\subsubsection{Income Section}

The Following is the Percentage of Respondents from the Income Side

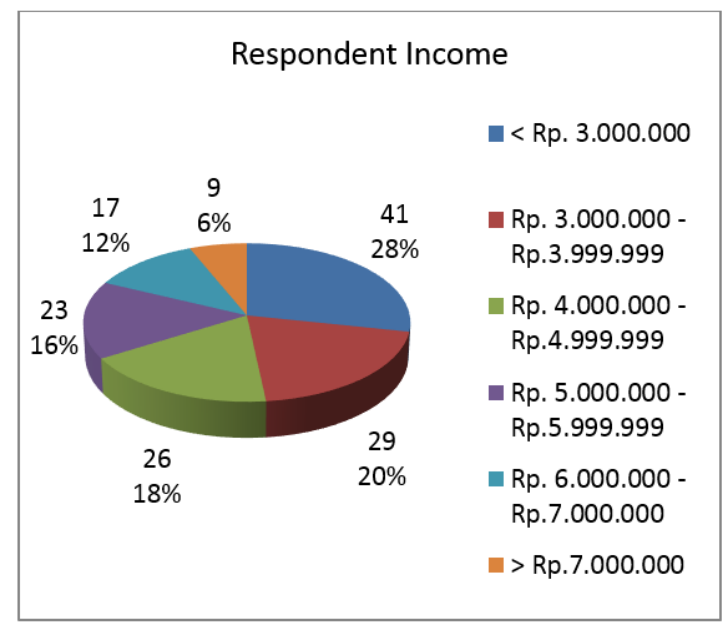

Fig. 2. Respondent Income

The income level of respondents in this study was dominated by respondents with an income level of $<$ Rp. $3,000,000$, that is a number of 41 respondents $(28 \%)$, and the lowest 9 respondents $(6 \%)$ had an income level> Rp. 7,000,000.

\subsubsection{The frequency of consumers in visiting restaurants}




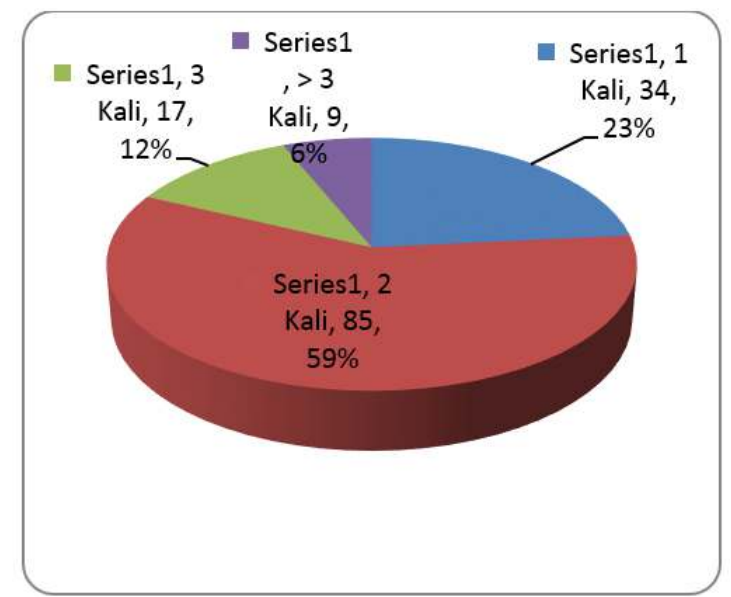

Fig. 3. The frequency of consumers in visiting restaurants

As presented in Figure 3, it can be seen that the average consumers visit the restaurant 2 times a month which is $59 \%, 12 \%$ of them visit 3 times a month, $23 \%$ of them visit 1 time a month and only $6 \%$ of them visit more than 3 times a month.

\subsection{Discussion}

\subsubsection{Variable Consumer Satisfaction}

Variables of consumer satisfaction are measured by referring to several indicators, including customer perception of product quality, customer perception of service quality, price and situation factors and consumer personalities

Table 1. Average Variable of Consumer Satisfaction

\begin{tabular}{lll}
\hline $\begin{array}{l}\text { N } \\
\text { o. }\end{array}$ & \multicolumn{1}{c}{$\begin{array}{c}\text { Variable of Customer } \\
\text { Satisfaction }\end{array}$} & $\begin{array}{c}\text { Nilai } \\
\text { Rata- } \\
\text { Rata }\end{array}$ \\
\hline 1. & $\begin{array}{l}\text { I am satisfied with food at } \\
\text { fast food restaurants }\end{array}$ & 4,17 \\
\hline 2. & $\begin{array}{l}\text { The price of food in fast food } \\
\text { restaurants is in line } \\
\text { with my income }\end{array}$ \\
\hline 3. & $\begin{array}{l}\text { The price of food in fast } \\
\text { food restaurants is in line } \\
\text { with my income }\end{array}$ \\
\hline 4. & $\begin{array}{l}\text { I always talk about positive } \\
\text { things about fast food } \\
\text { restaurants to others }\end{array}$ \\
\hline Mean
\end{tabular}

\subsubsection{Test Measurement Model}

Source : Primary Data, 2018 
The following figure shows the relationship between indicators and unobserved variables

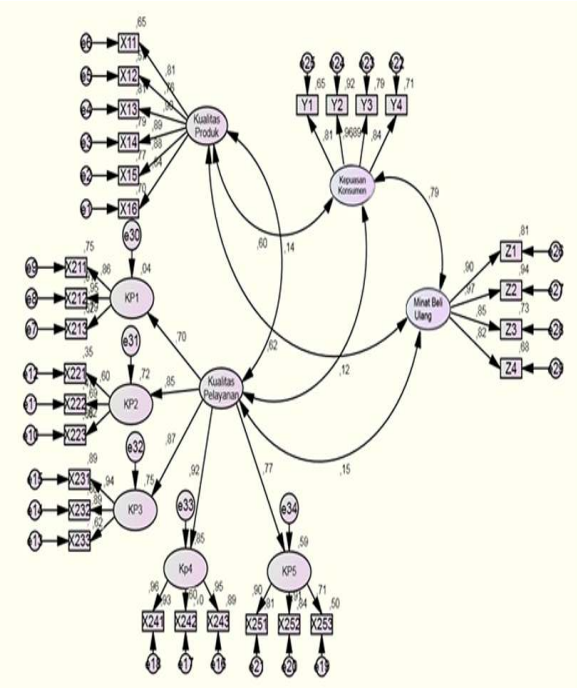

Fig. 4. Measurement Model with Loading Factor

The following table shows the relationship of indicators with their respective constructs. Loading factor is used if the value is above 0.6 , then the indicator is said to be representative enough to explain the unobserved variable.

Table 2. Loading Factor Variables of Product Quality

\begin{tabular}{cccc}
\hline Indicator & & Variable & Loading Factor \\
\hline X11 & $\leftarrow$ & Product Quality & 0,807 \\
\hline X12 & $\leftarrow$ & Product Quality & 0,756 \\
\hline X13 & $\leftarrow$ & Product Quality & 0,899 \\
\hline X14 & $\leftarrow$ & Product Quality & 0,889 \\
\hline X15 & $\leftarrow$ & Product Quality & 0,880 \\
\hline X16 & $\leftarrow$ & Product Quality & 0,839 \\
\hline \multicolumn{4}{c}{ Source : Primary Data, 2018 }
\end{tabular}

Tabel 3. Loading Factor Variabel of Service Quality

\begin{tabular}{lllc}
\hline Indicator & & Variable & Loading Factor \\
\hline Tangible & $<---$ & Service Quality & 0,701 \\
\hline Reliability & $<---$ & Service Quality & 0,846 \\
\hline Insurance & $<---$ & Service Quality & 0,867 \\
\hline Responsiveness & $<---$ & Service Quality & 0,924 \\
\hline Emphaty & $<---$ & Service Quality & 0,770 \\
\hline
\end{tabular}

Source : Primary Data, 2018

Indicator loading factor of unobserved Service Quality variable that has the highest score is in the "responsiveness" sub variable, which is 0.924 , which means that this sub variable 
contributes $92.4 \%$ percent to the Service Quality variable. This means that fast food restaurants in Banda Aceh, if they want to improve their service quality, then the sub-variables "responsiveness must get top priority compared to other dimensions.

The results of the study provide information that the interest in satisfying consumers of fast food restaurants in Banda Aceh is positively influenced by the quality of products and services, if the restaurant manager as the decision maker can improve all aspects of product quality such as taste, packaging, attractive forms so it will have an impact a positive increase in sales.

\section{Conclusion}

The results of this study indicate that product quality and customer satisfaction are good at Fast Saji Restaurants in Banda Aceh while service quality is not good Product quality variables and service quality have a positive effect on customer satisfaction

\section{Suggestions}

It is recommended to decision makers at the Fast Food Restaurant in Banda Aceh to be able to improve aspects of physical evidence, especially adequate parking areas, other supporting facilities such as wastafle, toilet hand dryer. In addition, decision makers in restaurants also still need to improve and improve employee performance, timeliness of service, speed of service and the way employees communicate with consumers.

It is expected that decision makers in the Fast Food Restaurant in Banda Aceh will improve customer satisfaction to improve product quality.

\section{Thank-You Note}

To Prof. Dr. Jasman, J. Ma'ruf, SE, MBA (The Rector of Teuku Umar University), Dean, Vice Dean I and II, Head of Study Program / Secretary of EKM Study Program, and Academic Community of FE UTU and all parties that cannot be mentioned individually.

\section{References}

[1] Arief, M. (2007) Pemasaran Jasa Dan Kualitas Pelayanan: Bagaimana Mengelola Kualitas Pelayanan agar Memuaskan Pelanggan. Malang: PT Bayumedia Publishing.

[2] Ferdinand, A. (2014) Research Methods For Managent. Edisi keli. Semarang: BPUNDIP.

[3] Kinnear, T. C. and Taylor, J. R. (2003) Riset Pemasaran. Edisi Terj. Jakarta: Erlangga.

[4] Zeithaml, P. V. A. and Bitner, G. (2010) Service Marketing: Integrating Customer Focus Across The Firm. Second Edi. New York: McGraw Hill Inc. 